\title{
Logistics Modeling of Multimodal Transport of Cargo from Origin to Destination: An Empirical Case of Chemical Cargo from Java to Both Java and Sumatera Points
}

\author{
Raja Oloan Saut Gurning1, I Ketut Gunarta2, Hera Widiastuti3, Felix Andrian2, Wahju Herijanto3, Catur \\ Arif Prastyanto3, Anak Agung Gde Kartika3, Dimas Wantoro1 \\ ${ }^{1}$ Jurusan Teknik Sistem Perkapalan, Fakultas Teknologi Kelautan, Institut Teknologi Sepuluh Nopember (ITS) \\ Surabaya \\ ${ }^{2}$ Jurusan Teknik Industri, Fakultas Teknologi Industri, Institut Teknologi Sepuluh Nopember (ITS) Surabaya \\ ${ }^{3}$ Jurusan Teknik Sipil, FakultasTeknik Sipil, Lingkungan \& Kebumian., Institut Teknologi Sepuluh Nopember \\ (ITS) SurabayaJl. Arif Rahman Hakim, Sukolilo, Indonesia. sautg@its.ac.id
}

\begin{abstract}
To build an efficient transportation system product, possible alternatives paths and modes of transportation for all types of products to be marketed and distributed are signifcant requirements need to be mapped by logistics operator. It becomes more complex due to each product type has its own characteristics and market objectives, thus this is requiring the design of transport schemes that can accommodate those needs in addition to be able to meet its sales target of cargo producers, both in terms of selling volume and revenue. Selection of the appropriate transport scheme is one of the key to achieve efficiency in companies' operation. Therefore, this study explores the comprehensive transportation process including the route and its capacity, vehicle, cargo volume and the time so that the objectives to transport the cargo is achieved. At the result, the logistics model using networking analysis by Excel and ARENA that has been aplied in this study may be used as optimization method of transporting and distributing cargoes including able to provide recommendations pattern / scheme of transport and logistics effectively and efficiently from Java to both various points in Java and Sumatera

Keywords: Logistics modeling, multimodal transport, Chemical cargo, Java and Sumatera
\end{abstract}

\section{BACKGROUND}

One company plans to produce petrochemical products by type: Polyethylene (ore), Polypropylene (ore), MEG (Liquid), started in 2022, with the capacity of each as follows:

- Polyethylene : $700 \mathrm{KTA}$

- Polypropylene : 550 KTA

- $\quad$ MEG : $460 \mathrm{KTA}$

- $\quad$ DEG/TEG : 46/4,6 KTA

Refinery products is planned to be located in Tuban, with the aim for sending to various locations on the island of Java. To support the plan, The requires effective and efficient planning transport schemes.

To build an efficient transportation system product, possible alternatives paths and modes of transportation for all types of products to be marketed firstly need to be mapped. Each product type has its own characteristics and market objectives, thus this is requiring the design of transport schemes that can accommodate those needs in addition to be able to meet its sales target of the company, both in terms of selling volume and revenue. Selection of the appropriate transport scheme is one of the key to achieve efficiency in companies' operation. Therefore, comprehensive transportation study is required in objectives to transport the model with optimization method that is able to provide recommendations pattern / scheme of transport and logistics effectively and efficiently.

\section{METHOD USED}

Before building the model by software, first, we have to build a conceptual model, so that the logic of modeling does not let an error. For the detail the conceptual model can be seen in Figure 1 below. 


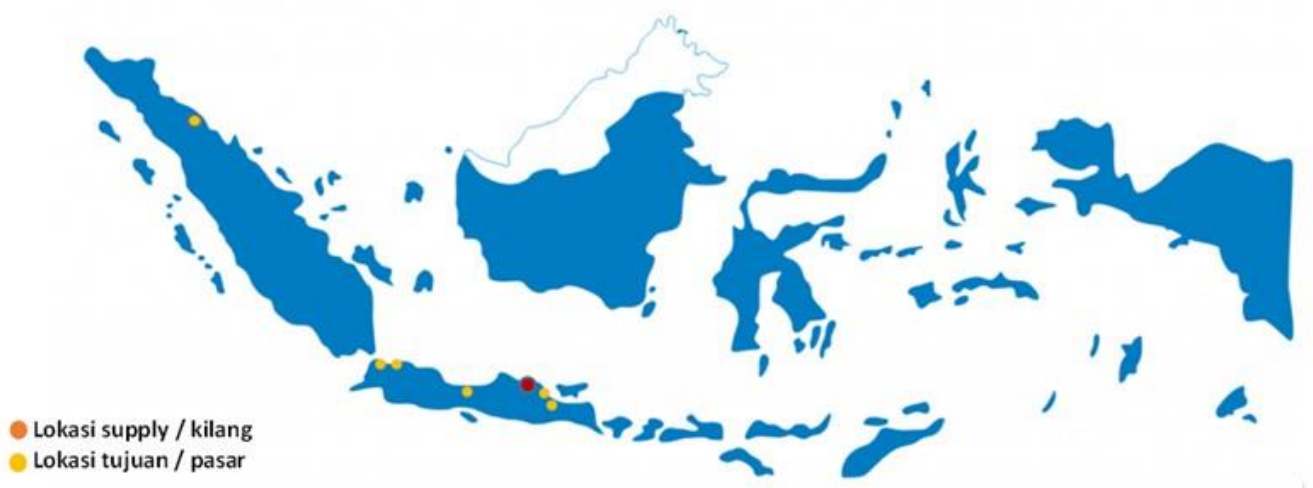

In this conceptual model, it is starting with clustering of each vessel based on size of DWT, where previously have been discussed. Furthermore, based on the stage of data processing that has been done, we get for each cluster ship to check each jetty to be idle or not, the vessel will enter when jetty empty, then will be in the process of berthing, transferring, and unberthing. The process that occurs at each jetty have to be calculated into the turn round time [1], [2], whereby these results with the factor of time total docking in one year and the number of moorings in the terminal will be used as a factor for The BOR calculations as seen in Figure 1 below.

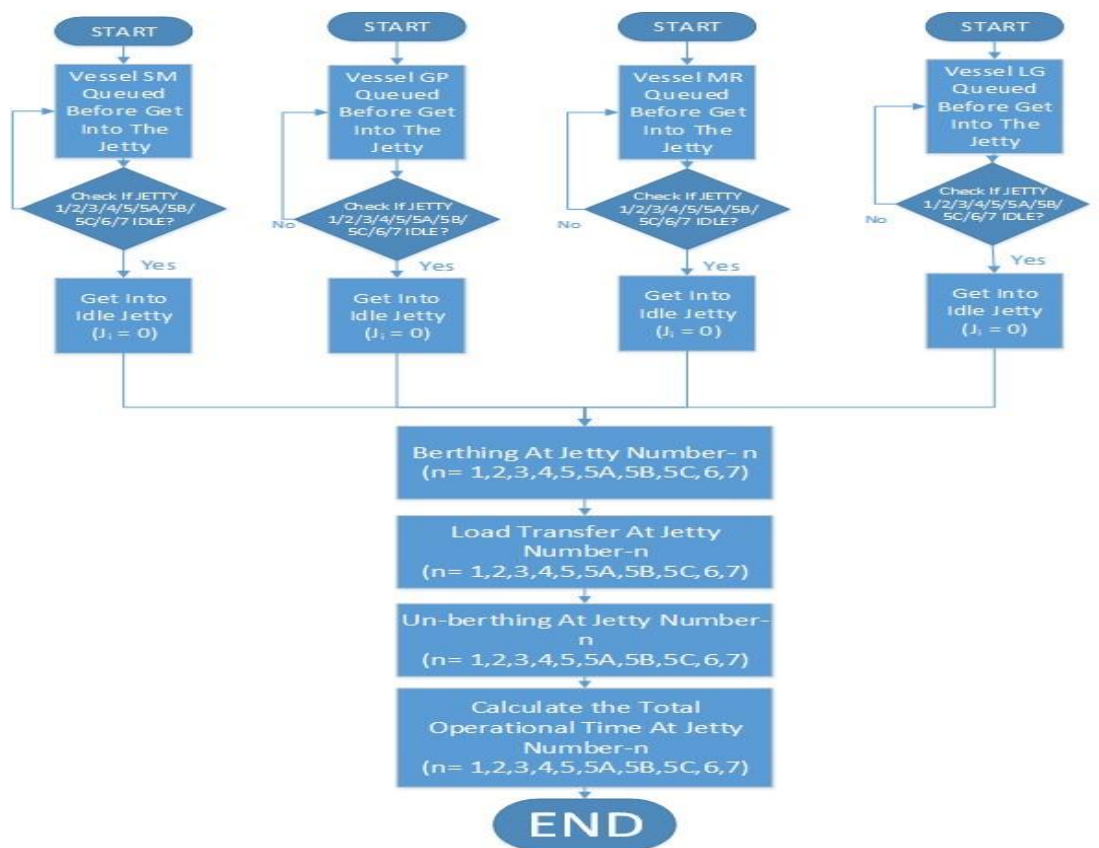

Figure 1. The flow chart of simulation process

For the detail of BOR calculation, can be seen on the formula:

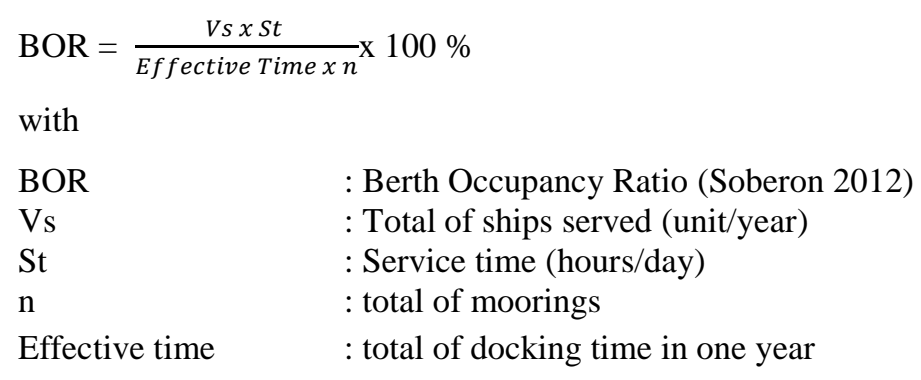

\section{MODELING AND SCENARIOS RESULTS}


The running result of existing model shows the actual condition of BOR at each jetty. Based on the recommendation of UNCTAD, BOR value above $60 \%$ is categorized as "high", while value below $60 \%$ is categorized as "low". On the result of the existing model, almost the entire jetty in the category of high BOR. The highest BOR in the category of "high" is jetty number 2 with a value of $79 \%$ while the lowest is jetty number $5 \mathrm{C}$ with a value of $61 \%$. The BOR value for category "low" is jetty number $5 \mathrm{~A}$ with a value of $33 \%$. Several scenarios have been set at the beginning will be made as experiment to do some improvement at each jetty. The best scenario is a scenario that can generate "low" BOR value at each jetty.

Table 2. BOR value of existing condition at each jetty.

\begin{tabular}{|cccc|}
\hline \multicolumn{4}{c|}{ Existing Operation } \\
\hline Jetty & $\begin{array}{c}\text { Total Round } \\
\text { (hour) }\end{array}$ & BOR & $\begin{array}{c}\text { BOR } \\
\text { Category }\end{array}$ \\
\hline 1 & 6254 & $77 \%$ & High \\
2 & 6449 & $79 \%$ & High \\
3 & 5459 & $67 \%$ & High \\
4 & 5206 & $64 \%$ & High \\
5 & 5929 & $73 \%$ & High \\
5A & 2671 & $33 \%$ & Low \\
5B & 5899 & $72 \%$ & High \\
5C & 4986 & $61 \%$ & High \\
\hline Total & 42853 & $66 \%$ & \\
\hline Cargo & 17.153 .512 & \\
\hline
\end{tabular}

In this study, there are several considerations in determining the value of BOR in the terminal, among others, the first value is BOR allowed by UNCTAD (2000) has a maximum value of BOR 60-65 percent, the second consideration to continue to anticipate the rising volume of cargo handling oil and gas that can be handled the terminal in the future (Bassan, 2007). The third, a value BOR high large potential cause various additional costs, especially the cost of waiting time that will be new problems not only for the terminal as an operator, but also public service users who wants a gas distribution process more efficient and effective, and therefore in addition to trying to evaluate from existing models that have been made, also required a system model scenarios in the terminal activity. Where in these scenarios, trying to give an option to obtain an effective value of BOR to fulfill considerations mentioned above.

By sampling conducted from January-April 2016, there were approximately 457 hours as a vessel total waiting time due to various problems, obstacles, or lack of jetty facilities and operation management. In addition, from the model reselts can also inform that jetty number 2, 3, 4, and 5 needs a special concern. Mainly jetty number 4 has a dominant waiting time constraint compared to other jetties. Though, several inhibiting factors or waiting time occurs in all jetties. The main factor of high waiting time in jetty number 4 is caused by waiting for availability of jetty number 4 when it still utilized by another ship. While other minor factors are caused by waiting for document, the amount of cargo, cargo calculation, laboratory analysis, wait for a pilot, and low pace of pump including MLA. Hence, Jetty number 4 need to be a main concern in development of te terminal in the future especially with increasing demand for crude oil cargo, LSWR, aviation fuel, kerosene, premium, HOMC, HSD, MFO, ADO, Afigas, Naptha, and HVGO. The indication of high waiting time in jetty number 2, 3, 4, and 5 seems comparable to BOR level owned by each jetty. It can be ascertained that the high BOR value in four jetties fundamentally caused by high waiting time. From the observation during the survey, the root cause of the problem may be due to low carrying capacity of the infrastructure, especially the pier or jetty and loading-unloading equipment (MLA). However, it also can be caused by soft-structure in the form of various ways of managing or arrangement and the use of ICT technology in accelerating document process or monitoring various operational activities. With a determined the amount of cargo 32 million tons, then the next stage is to discuss how simulation scenarios that try used to be the fulfillment of these options, and for details on the scenarios that have been defined can be seen in Table.3.

There are nine alterntive scenarios focusing on technical, operational, adminsitrative and commercial in reducing the BOR level of the terminal including optimising the level of throughput achieving at 32 million tons of oil and gas related cargo. 


\begin{tabular}{|c|l|}
\hline No & \multicolumn{1}{|c|}{ Scenario Model } \\
\hline $\mathbf{1}$ & The pattern of arrival of the vessel accelerated 30\% \\
\hline $\mathbf{2}$ & The pattern of arrival of the vessel accelerated 50\% \\
\hline $\mathbf{3}$ & $\begin{array}{l}\text { The pattern of arrival of the vessel accelerated 50\% + Increasing of capacity MLA } \\
\text { until 150\% at each Jetty }\end{array}$ \\
\hline $\mathbf{4}$ & $\begin{array}{l}\text { The pattern of arrival of the vessel accelerated 50\% + Increasing of capacity MLA } \\
\text { until 200\% at each Jetty }\end{array}$ \\
\hline $\mathbf{5}$ & $\begin{array}{l}\text { The pattern of arrival of the vessel accelerated 50\% + Decreasing of Waiting Time } \\
10 \% \text { (Document) }\end{array}$ \\
\hline $\mathbf{6}$ & $\begin{array}{l}\text { The pattern of arrival of the vessel accelerated 50\% + Decreasing of Waiting Time } \\
30 \% \text { (Document + Hose connect \& disconnect + Berthing \& Unberthing) }\end{array}$ \\
\hline $\mathbf{8}$ & $\begin{array}{l}\text { The pattern of arrival of the vessel accelerated 50\% + Decreasing of Waiting Time } \\
50 \% \text { (Document + Hose connect \& disconnect + Berthing \& Unberthing + Waiting for } \\
\text { pilot vessel) }\end{array}$ \\
\hline $\mathbf{9}$ & $\begin{array}{l}\text { The pattern of arrival of the vessel accelerated 50\% + Decreasing of Waiting Time } \\
50 \% \text { (Document + Hose connect \& disconnect + Berthing \& Unberthing + Waiting for } \\
\text { pilot vessel)+ Increasing of capacity MLA until 200\% at each Jetty }\end{array}$ \\
\hline \\
$\begin{array}{l}\text { The pattern of arrival of the vessel accelerated 50\% + Decreasing of Waiting Time } \\
\text { pilot vessel) + Increasing of capacity MLA until 200\% in each Jetty + Increacing } \\
\text { Capicity of Vessel's Cargo + adding metering at each Jetty }\end{array}$ \\
\hline
\end{tabular}

\section{CONCLUSION}

From the experimental result of scenario 1 and 2, BOR Value in "high" category for all jetties except Jetty 5A. And from the total cargo in scenario 1 and 2 not yet to fulfill commercial plan in 2020, 32 million tons. So it can be said that scenario 1 and 2 rejected. Further, if scenarios 3 and 4 analysed then the BOR value is calculated as high category for all jetties except Jetty 5A. so it can be said that scenario 3 and 4 like scenario 1 and 2, are rejected. Similarly, From the experimental result of scenario 4,5 and 6 , BOR Value and total cargo like previous scenarios. So it can be said that scenario 5,6, and 7 are also rejected. Furter, isf scenaro 8 is analysed, it is stated that of scenario 8 can get the information that generate lower BOR Value compared to previous scenarios. However, the total cargo in scenario 8 is unable to fulfill commercial plan in 2020, which is about 32 million tons. So it can be said too that scenario 8 like previous scenarios are further rejected. Finally, scenario 9 is the only effort that may generate a lower BOR including fulfill the commercial plan throughput in 2020 which is about 32 million tons. Therefore, it can be stated that scenario 8 is fully accepted.

\section{DAFTAR PUSTAKA}

[1] J. D. Griffiths, "Optimal handling capacity at a berth,” Marit. Stud. Manag., vol. 3, no. 3, pp. 163-167, Jan. 1976.

[2] G. G. Brown, S. Lawphongpanich, and K. P. Thurman, “Optimizing ship berthing,” Nav. Res. Logist., vol. 41, no. 1, pp. 1-15, Feb. 1994. 